\title{
AN EXAMINATION OF PERCEIVED QUALITY, SATISFACTION, AND LOYALTY RELATIONSHIP Applicability of Comparative and Noncomparative Evaluation
}

\author{
Licen IndahwatiDarsono \\ C.Marliana Junaedi
}

This paper evaluates alternative measurement approaches to investigating the relationship amongst perceived quality, customer satisfaction, and loyalty. The authors define and measure the constructs within a relative attitudinal framework and compare these results to a noncomparative or individual evaluation of brands. In addition, loyalty is measured by and defined as a behavioral and attitudinal loyalty. The object of this research is teh botol whilst the subjects are undergraduate students in Surabaya and Yogyakarta.

The proposed model, with satisfaction as a mediator between quality and loyalty, is found to be an acceptable representation of data across three brands of teh botol and for both comparative and noncomparative evaluation. The use of relative attitude, however, indicates a much stronger relationship amongst perceived quality, satisfaction, and loyalty than the attitude towards a brand when they are performed in individual evaluation. With respect to predictive ability, this study's findings suggest that comparative evaluation has higher degree of applicability than does noncomparative evaluation.

Keywords: comparative and noncomparative evaluation; loyalty; perceived quality; satisfaction 
Gadjah Mada International Journal of Business, September - December 2006, Vol. 8, No. 3

\section{Introduction}

The central thrust of the marketing activities of a firm is often viewed in terms of development, maintenance, or enhancement of customer loyalty. Indeed, customer loyalty represents an important basis for developing sustainable competitive advantage (Dick and Basu 1994). A loyal customer base can be a valuable asset for any firm, which reduces the need to seek new customers and may act as a barrier to switching behavior (Ruyter and Bloemer 1999; Rowley and Dawes 2000). Accordingly, there is substantial ground to believe that there is a link between loyalty and profitability (Hallowell 1996; Rowley and Dawes 1999).

Both perceived quality and customer satisfaction are two central issues in promoting customer loyalty. Many firms allocate substantial resources to measure and monitor quality, satisfaction, and loyalty in order to retain customers and improve performance. Perceived quality is the antecedent of satisfaction (Szymanski and Henard 2001) where higher quality leads to higher customers satisfaction. Hallowel (1996); Bloemer and Ruyter (1998); Mittal and Lassar (1998); Kandampuly and Suhartanto (2000); Bowen and Chen (2001) report that customer satisfaction has a positive relationship with customer loyalty. Hence, the antecedent and outcome of satisfaction are perceived quality and loyalty.
Studies on perceived quality and satisfaction are more focused on how quality and satisfaction can be improved (Mittal and Lassar 1998), customer satisfaction-purchase intension and behavioral relationship (Mittal and Kamakura 2001), customer satisfaction-loyalty relationship (Hallowel 1996; Oliver 1999; Kandampully and Suhartanto 2000; Bowen and Chen 2001). Despite the extensive discussion of the perceived quality and satisfaction constructs, only a few empirical studies have tested perceived quality-satisfaction-loyalty relationship simultaneously (Zeithaml 2000; Olsen 2002). It motivates the authors to simultaneously investigate perceived quality-satisfaction-loyalty relationship.

However, previous studies find contradictory results. Satisfied customers are not always loyal (Rowley and Dawes 2000), and the satisfaction-loyalty relationship is not necessarily linear (Soderlund 1998). Parallel with these arguments, Jones and Sasser (1995); Mittal and Lassar (1998) document that satisfied customers are still defective. Meta-analysis towards 50 empirical studies on customer satisfaction finds that the strength of the relationship between antecedents and consequences of satisfaction are moderated by measurement and research methods (Symanski and Henard 2001). Therefore, the authors are more focused on the measurement issues of perceived quality, satisfaction, and loyalty. 
Dick and Basu (1994) propose that there are advantages to comparing brands viewed by customers to be relevant in a given consumption context. They suggest that using a relative attitude terminology in measuring customer loyalty is likely to provide stronger indication of repeat patronage than the individual evaluation of a product. Dick and Basu's (1994) argument is supported by Laroche et al. (1994). They report that a potential customer always conducts comparative evaluation towards a brand when she is in stage of attitude formation. Hence, relative attitude conceptualization is used to measure customer loyalty, and both individual (noncomparative) evaluation and comparative evaluation are used to measure perceived quality and satisfaction. The purpose of this research is to compare the predictive power of comparative evaluation versus noncomparative evaluation in investigating perceived quality-satisfaction-loyalty relationship.

This research differs from previous research (Olsen 2002) with respect to loyalty measurement. Olsen (2002) uses behavioral measures of repurchase loyalty, including the proportion of purchase, the purchase sequence, and the probability of purchase. However, this researchuses both attitudinal and behavioral measures. Lau and Lee (1999) argue that attitudinal measures are much more important and beneficial, provided that the attitude basically drives behavior. Whilst behavioral loyalty is partly determined by situational factors, atti- tudes are more enduring. O'Malley (1998) states that attitudinal measures are a poor predictor of behavior. Therefore, it seems that neither attitudinal nor behavioral measure itself is sufficient to explain or define loyalty. The use of both attitudinal and behavioral measures in loyalty definition substantially increases the predictive power of loyalty (Pritchard and Howard 1997 as cited by Bowen and Chen 2001). This research also differs from Olsen's (2002) study on research setting. Olsen (2002) uses people responsible for preparing the family dinner in the household as the subjects and seafood products as the research objects. Meanwhile, this research uses people who ever drink three brands of teh botol as the subjects and teh botol per se as the research object.

\section{Research Model and Hypothesis}

\section{Perceived Quality}

Quality can be defined broadly as superiority or excellence. Specifically, perceived quality can be defined as customer's judgement about product's overall excellence or superiority (Zeithaml 1988). Zeithaml (1988) argues that there are two forms of quality: (1) objective quality and (2) perceived quality. Objective quality refers to the actual technical superiority or excellence of the products. In this way, objective quality can be verified using some predetermined measurable ideal standard or standards. Concern 
centres on the selection of attributes and weights to measure objective quality since researchers and experts do not agree on what the ideal standard or standards should be. Maynes (1976) as cited by Zeithaml (1988) claims that objective quality does not exist, and that all quality evaluation is subjective. This argument supports the second form of quality, perceived quality. Zeithaml (1988) defines perceived quality as consumer's judgement about a product's overall excellence or superiority.

The authors have the same argument as Zeithaml's (1988). Therefore, the term of quality in this research refers to perceived quality. Perceived quality is defined and measured as a statement of belief or attribute performance (Churchil and Surprenant 1982 as cited by Olsen 2002).

\section{Customer Satisfaction}

The central theme in the satisfaction definition is the expectancydisconfirmation paradigm. According to this paradigm, customers form expectations, which act as a standard against which product or service performance will be judged. A comparison of expectations and perceptions will result in either confirmation or disconfirmation. Customer's expectations are confirmed when the product or service perceptions exactly meet expectations. Disconfirmation will be the result of a discrepancy between the expectations and the perceptions. Two types of disconfirmation can be identi- fied: (1) positive disconfirmation occurs when product performance exceeds prior expectations and (2) negative disconfirmation prevails when expectations exceed performance. Confirmation and positive disconfirmation will be likely to result in satisfaction, whereas negative disconfirmation leads to dissatisfaction. Therefore, Oliver (1996) as cited by Ruyter and Bloemer (1999) reveals that satisfaction is perceived to be a post-consumption evaluation or a pleasurable level of consumption-related fulfillment.

The authors have the same argument as that of Oliver (1996). Accordingly, satisfaction in this research is based on Oliver's (1994) conceptualization, by which satisfaction is defined as pleasurable fulfillment, meaning that consumption fulfils some needs, desires, goals, or so forth of customers and this fulfillment is pleasurable. With respect to this definition, satisfaction reflects the impact of product or service performance on people's feeling state (Rosenberg 1960 as cited by Olsen 2002). The customers feel that the level of fulfillment is pleasant or unpleasant.

\section{Perceived Quality and Customer Satisfaction}

High correlation between perceived quality and customer satisfaction raises contrary arguments amongst researchers about the order of occurrence between perceived quality and satisfaction (Parasuraman et al. 1994). 
However, most marketing researchers accept a theoretical framework in which perceived quality leads to satisfaction, especially when perceived quality is framed as a specific belief evaluation and satisfaction as a more general evaluative construct (Gotlieb et al. 1994; Johnson et al. 2001 as cited by Olsen 2002). As a result, satisfaction is one facet of a global affective evaluation that can be predicted from quality belief as a cognitive component of the evaluation. Johnson (1998) as cited by Szymanski and Henard (2001) states that a customer is more likely satisfied with marketer's offerings when they have higher capabilities of fulfilling customers' needs and wants. Thus, perceived quality is the antecedent of customer satisfaction and has a positive impact on customer satisfaction.

\section{Loyalty}

The loyal object might be a brand, product, organization, or service outlet. However, much of the literature on customer loyalty has looked at brand loyalty (Rowley and Dawes 1999). Dharmmesta (1999) points out that brand is often viewed as a loyal object, given that it represents a product or firm identity easily recognized by customers. With respect to this situation, customer loyalty and brand loyalty terminologies in this article are of no differenceand can be used interchangeably.
Attempting to define loyalty is much easier to be said than done. In general, there are three distinctive approaches to measuring loyalty:

1. Behavioral measurement,

2. Attitudinal measurement, and

3. Composite measurement.

The behavioral measurement considers consistent, repetitious purchase behavior as an indicator of loyalty. One problem with the behavioral measures is that repeat purchases are not necessarily the results of psychological commitment towards the brand (TePeci 1999 as cited by Bowen and Chen 2001). Hence, repeat purchases do not always mean commitment.

Attitudinal measurement uses attitudinal data to reflect the emotional and psychological attachment inherent in loyalty. The attitudinal measurement is concerned about the sense of loyalty, engagement, and allegiance (Bowen and Chen 2001).

The third approach, composite measurement of loyalty, combines the first two dimensions and measures loyalty by customer's product preferences, propensity to switch, frequency of purchase, recency of purchase, and total amount of purchase. The use of both attitudinal and behavioral measurements in loyalty definition substantially increases the predictive power of loyalty (Bowen and Chen 2001). The composite approach has been applied and supported by several researchers. Mowen and Minor as cited 
Gadjah Mada International Journal of Business, September-December 2006, Vol. 8, No. 3

by Dharmmesta (1999) define brand loyalty as consisting of repeat purchases prompted by a strong positive attitude and commitment towards the brand. Parallel with Mowen and Minor, Oliver defines brand loyalty as a deeply held commitment to rebuying or repatronizing a preferred product/ service consistently in the future, thereby causing repetitive same-brand or same brand-set purchasing, despite situational influences and marketing efforts having the potential to cause switching behavior. Dick and Basu (1994) define loyalty as the strength of the relationship between individual's relative attitude and repeat patronage.

The primary contribution of Dick and Basu (1994) lies in relative attitude. Not only does the relative attitude focus on attitude towards the brand, but it also incorporates attitudes to alternatives. This encapsulates not only satisfaction measures but also preference measures. The suggestion is that the higher the relative attitude amongst alternatives, the more likely the attitude will influence behavior. Dick and Basu (1994) argue that the nature of relative attitude is likely to provide a stronger indication of repeat patronage than of attitude towards a brand determined in isolation. Dick and Basu's (1994) argument for using relative attitude is supported by Laroche et al. (1994); Olsen (2002). They report that a potential customer always conducts comparative evaluation towards a brand when she is in stage of attitude formation.

\section{Customer Satisfaction and Loyalty}

The satisfaction-loyalty relationship has been much debated in the literature. Strauss and Neuhaus (1997); Rowley and Dawes (1999) propose that the relationship between satisfaction and loyalty is nonlinear, resulting from the tendency to remain loyal in spite of the pressure of switching incentives. The role of satisfaction is not clear as a number of customers who express satisfaction still defect, and dissatisfied customers stay loyal. Hallowell (1996); Soderlund (1998); Ruyter and Bloemer (1999) Kandampully and Suhartanto (2000) state that increasing satisfaction does not produce an equal increase in loyalty for all customers. Oliver (1999) offers a possible explanation for the nonlinear relationship of satisfaction and loyalty. Satisfaction still has an important role as the antecedent of loyalty; however, its role is limited in affective loyalty. Oliver (1999) proposes that customers first become loyal in the cognitive sense, then later in affective sense, and still later in a conative, action, or behavioral manner. Affective loyalty is based on qualitybased satisfaction or price-based satisfaction. Quality-based and price-based satisfaction still has the vulnerability to do brand switching. The vulnerability to do brand switching is caused by customer dissatisfaction towards focal brand, other brand's persuasive efforts, and the customer's desire to seek variety and try other brands. Conclusively, 
the outcome of satisfaction is loyalty, and satisfaction per se has a positive impact on loyalty.

\section{Perceived Quality, Satisfaction, and Loyalty}

Regarding the traditional attitude theory (Fishbein and Ajzen 1975), perceived quality is defined as an evaluation on product performance. This evaluation hinges on customer's cognitive process. In other words, perceived quality represents cognitive component of evaluation. Satisfaction reflects the customer's affective evaluation on the impact of product performance on their feeling state. Hence, if the authors suggest that perceived quality is an evaluation on or appraisal of attribute performance, and that satisfaction reflects the impact of the performance on customer's feeling state, then perceived quality can be utilized to predict customer's feelings (satisfaction) or buying behavior.

Previous studies on loyalty (Jones and Sasser 1995; Hallowel 1996; Mittal and Lassar 1998; Oliver 1999; Kandampully and Suhartanto 2000; Bowen and Chen 2001) document that the outcome of satisfaction is loyalty. The authors accordingly propose a model to be structured in such a way that satisfaction acts as a mediator between perceived quality and loyalty (see Figure 1). This assumption is also in accordance with the cognition-affect-behavior paradigm (Fishbein and Ajzen 1995) and the loyalty phase framework (Oliver 1999).

Dick and Basu (1994) suggest that relative attitude (comparative evaluation) is likely to provide a stronger indication of repeat patronage than attitude towards a brand measured in isolation. Laroche et al. (1994) find that a potential customer always does comparative evaluation towards a brand when she is in stage of attitude formation. Van den Putte et al. (1996) as cited by Olsen (2002) argue that better prediction of behavior is the result of framing attitudes and other constructs as a direct comparison across relevant alternatives. Therefore, our hypothesis is:

The strength of relationship amongst perceived quality and satisfaction and loyalty will be greater when perceived quality and satisfaction are defined and measured as comparative evaluation of several brand alternatives functionally substitutable rather than as a noncomparative or individual evaluation of brand.

Figure 1. Research Model

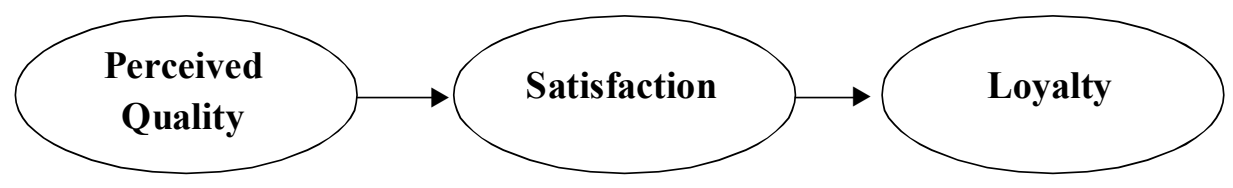


Gadjah Mada International Journal of Business, September-December 2006, Vol. 8, No. 3

\section{Method}

Objects, Subjects, and Procedures

Three brands of teh botol: Sosro, Fruitea, and Frestea, are selected as research objects with the consideration that preferences and perceived quality of Sosro, Fruitea, and Frestea seem to vary. The subjects of this research are undergraduate students in Surabaya and Yogyakarta who ever consume Sosro, Fruit Tea, and Frestea.

The first procedure was to divide respondents into two groups. One group received the measuring instrument requiring them to rate all attributes of a brand before moving to the next brand. This noncomparative format is so-called the "entity-based format" by Teas and Wong (1992). The second group received the instrument that required them to rate all the three brands on one attribute before moving to the next attribute. This comparative format is also termed the "attribute-based format" (Teas and Wong 1992).

\section{Questionnaires and Format}

Two versions of questionnaire were developed. The questions and their order in the two versions are of no difference. The question order is started with general, global questions, satisfaction, then followed by more specific questions, perceived quality evaluation and loyalty (Malhotra 2002). The final section of the questionnaires contains general informa- tion on respondents. The only difference between the two questionnaires is the comparative and noncomparative format. The noncomparative format has one page with all the satisfaction and perceived quality items for one brand, followed by the next brand, and then the third. On the other hand, the comparative format has one item (satisfaction items precede perceived quality attribute performance) for all the three brands such that all of them are salient for comparative evaluation. The order of the items is the same for all the three brands in the noncomparative format, and the brands are in the same sequence as they are in the comparative format.

\section{Measurement of the Constructs}

Perceived quality. Customer's evaluation of perceived quality is defined as and measured by the evaluation of attribute performance (Churchill and Suprenant 1982 as cited by Olsen 2002), associated with three different brands in this research. In a pilot study employing 40 respondents, the authors investigate positive and negative associations with quality of teh botol. High quality is associated with nice scent, sweet taste, and clean packaging. Meanwhile, low quality is associated with bad scent, bitter taste, and dirty packaging. All items are measured with a seven-point semantic differential scale, anchored by bad scent/nice scent, bitter taste/sweet taste, and dirty packaging/clean packaging. 
Satisfaction. Following Oliver's (1999) conceptualization, satisfaction is defined as and measured by the global evaluation of feeling state. The respondents are asked to indicate their overall feeling towards three different brands on a seven-point semantic differential scale anchored by dissatisfied/satisfied and unpleasant/pleasant states.

Loyalty. Predicated on Dick and Basu's (1994) conceptualization, loyalty is defined as and measured by attitudinal and behavioral dimensions. Attitudinal dimension is measured by commitment and intention whilst behavioral dimension is measured by purchase frequency and proportion of purchase. Three items are adapted from Lau and Lee (1999), two items are adapted from Pritchard et al. (1999). All items are measured using a sevenpoint interval scale.

\section{Results}

\section{Respondents Profile}

Of the 400 questionnaires distributed, 366 questionnaires were returned. After a careful examination, including a check on incomplete responses, monotonic answers, and outliers, only 173 responses (noncomparative evaluation) were usable and 163 responses (comparative evaluation) were usable.

Amongst the respondents, 56.4 percent of respondents have pocket money below IDR500,000, and approximately 34 percent have around IDR500,000-1,000,000, 9 percent have more than IDR1,000,000. The youngest respondent was 18 years old, and the oldest was 25 years old; most of them were ranging from 20 to 22 years old.

\section{Validation of Measures: Reliability and Validity}

First, the items measuring perceived quality, satisfaction, and loyalty are subject to a confirmatory factor analysis (CFA) to assess fit statistics (see Table 1). All of the chi-square values are significant; however, CMIN/ DF value is below the recommended level of 5 (Hair et al. 1998; Kenny 2002). The GFI and CFI values, however, are between 0.837 and 0.963 across brands and evaluation formats, far above the suggested fit level of 0.90 , and are considered acceptable (Hair et al. 1998; Kenny 2002). The other fit indices (AGFI and RMSEA) represent the marginal fit. Results in Table 1 imply that a two-factor solution is a reasonable representation of three brands and of comparative and noncomparative evaluation.

Additional measurement properties are presented in Table 2. Reliability is assessed utilizing construct reliability and Cronbach's alpha. Most of the investigated constructs exhibit construct reliability and alpha values of greater than 0.60 (see Table 2), suggesting reliability that exceeds the common acceptable level (Hair et al. 1998). The factor loadings (lambdas) are all reasonably high (above 0.4 ) and significant. All measures of variance ex- 
Gadjah Mada International Journal of Business, September-December 2006, Vol. 8, No. 3

Table 1 Fit Statistics of Measurement Model

\begin{tabular}{|c|c|c|c|c|c|c|}
\hline & \multicolumn{2}{|c|}{ Sosro } & \multicolumn{2}{|c|}{ Fruitea } & \multicolumn{2}{|c|}{ Frestea } \\
\hline & $\begin{array}{l}\text { Compa- } \\
\text { parative }\end{array}$ & $\begin{array}{c}\text { Non- } \\
\text { compa- } \\
\text { rative }\end{array}$ & $\begin{array}{c}\text { Compa- } \\
\text { rative }\end{array}$ & $\begin{array}{c}\text { Non- } \\
\text { compa- } \\
\text { rative }\end{array}$ & $\begin{array}{c}\text { Compa- } \\
\text { rative }\end{array}$ & $\begin{array}{c}\text { Non- } \\
\text { compa- } \\
\text { rative }\end{array}$ \\
\hline Quality $<>$ Satisfaction & 0.864 & 0.709 & 0.859 & 0.584 & 0.574 & 0.402 \\
\hline Quality $<>$ Loyalty & 0.563 & 0.564 & 0.555 & 0.428 & 0.292 & 0.223 \\
\hline Satisfaction $<>$ Loyalty & 0.635 & 0.695 & 0.638 & 0.572 & 0.640 & 0.564 \\
\hline$\chi^{2}$ & 95.024 & 65.950 & 80.700 & 70.706 & 148.908 & 146.498 \\
\hline Degree of freedom (df) & 32 & 32 & 32 & 32 & 32 & 32 \\
\hline Pvalue & .000 & .000 & .000 & .000 & .000 & .000 \\
\hline $\mathrm{CMIN} / \mathrm{df}$ & 2.97 & 2.061 & 2.522 & 2.210 & 4.653 & 4.578 \\
\hline GFI & 0.887 & 0.930 & 0.914 & 0.923 & 0.837 & 0.843 \\
\hline AGFI & 0.806 & 0.879 & 0.852 & 0.868 & 0.720 & 0.730 \\
\hline CFI & 0.942 & 0.963 & 0.947 & 0.961 & 0.891 & 0.906 \\
\hline RMSEA & 0.110 & 0.079 & 0.092 & 0.084 & 0.150 & 0.144 \\
\hline
\end{tabular}

tracted exceed 0.5 , with the exception for perceived quality. Hence, it can be concluded that the measurement model is substantially valid and reliable.

\section{Hypothesis Testing Results}

The proposed research model, with satisfaction as a mediator between perceived quality and loyalty, provides an acceptable fit across all brands and for both comparative and noncomparative evaluation (see Table 3). Three fit indices (GFI, AGFI, and CFI) are above 0.991, and RMSEA value is between 0.085 and 1 , whilst all chi-square values are insignificant. Accordingly, the authors conclude that the research model is similar and stable across brands and evaluation formats, providing us with a good basis for comparing both the relationship amongst the constructs and the model's predictive ability or explanatory power.

Table 3 indicates a relatively strong relationship between perceived quality and satisfaction, but this relationship varies amongst brands. Therefore, the findings substantiate Szymanski and Henard's (2001), Olsen's (2002) studies. The perceived quality-satisfaction relationship is much stronger for comparative evaluation than it is for noncomparative evaluation. Standardized path coefficients for comparative evaluation vary from 0.507 (Frestea) to 0.790 (Sosro) compared to from 0.329 (Frestea) to 0.642 (Sosro) when the three brands are framed in noncomparative evaluation. 
Darsono \& Junaidi-An Examination of Perceived Quality,Satisfaction, and Loyalty Relationship

Table 2. Scale Items, Factor Loadings, and Constructs Reliability

\begin{tabular}{|c|c|c|c|c|c|c|c|c|}
\hline \multirow{2}{*}{$\begin{array}{l}\text { Constructs } \\
\text { and } \\
\text { Indicator }\end{array}$} & \multicolumn{4}{|c|}{ Comparative Evaluation } & \multicolumn{4}{|c|}{ Noncomparative Evaluation } \\
\hline & $\begin{array}{l}\text { Standar- } \\
\text { dized } \\
\text { Loadings }\end{array}$ & $\begin{array}{c}\text { Cronbach } \\
\text { Alpha }\end{array}$ & $\begin{array}{l}\text { Compo- } \\
\text { site } \\
\text { Reliabi- } \\
\text { lity }\end{array}$ & $\begin{array}{l}\text { Variance } \\
\text { Extracted }\end{array}$ & $\begin{array}{l}\text { Standar- } \\
\text { dized } \\
\text { Loadings }\end{array}$ & $\begin{array}{c}\text { Cronbach } \\
\text { Alpha }\end{array}$ & $\begin{array}{l}\text { Compo- } \\
\text { site } \\
\text { Reliabi- } \\
\quad \text { lity }\end{array}$ & $\begin{array}{l}\text { Variance } \\
\text { Extracted }\end{array}$ \\
\hline \multicolumn{9}{|l|}{$\begin{array}{l}\text { Perceived } \\
\text { quality: }\end{array}$} \\
\hline Sosro & & 0.6998 & 0.7089 & 0.4490 & & 0.6653 & 0.6915 & 0.442 \\
\hline K1 & 0.667 & & & & 0.652 & & & \\
\hline K2 & 0.725 & & & & 0.836 & & & \\
\hline K3 & 0.614 & & & & 0.449 & & & \\
\hline Fruitea & & 0.6482 & 0.6608 & 0.4003 & & 0.7015 & 0.7234 & 0.478 \\
\hline $\mathrm{K} 1$ & 0.641 & & & & 0.785 & & & \\
\hline K2 & 0.741 & & & & 0.781 & & & \\
\hline K3 & 0.490 & & & & 0.457 & & & \\
\hline Frestea & & 0.6904 & 0.6953 & 0.434 & & 0.7885 & 0.792 & 0.5737 \\
\hline K1 & 0.604 & & & & 0.721 & & & \\
\hline K2 & 0.745 & & & & 0.945 & & & \\
\hline K3 & 0.619 & & & & 0.556 & & & \\
\hline \multicolumn{9}{|l|}{ Satisfaction: } \\
\hline Sosro & & 0.9212 & 0.9253 & 0.861 & & 0.8949 & 0.8953 & 0.8105 \\
\hline S1 & 0.933 & & & & 0.919 & & & \\
\hline S2 & 0.923 & & & & 0.881 & & & \\
\hline Fruitea & & 0.9048 & 0.9065 & 0.829 & & 0.9202 & 0.9204 & 0.8525 \\
\hline S1 & 0.926 & & & & 0.938 & & & \\
\hline S2 & 0.895 & & & & 0.909 & & & \\
\hline Frestea & & 0.9176 & 0.9200 & 0.8520 & & 0.9323 & 0.9319 & 0.8725 \\
\hline S1 & 0.890 & & & & 0.939 & & & \\
\hline S2 & 0.955 & & & & 0.929 & & & \\
\hline
\end{tabular}


Gadjah Mada International Journal of Business, September-December 2006, Vol. 8, No. 3

Continued from Table 2

\begin{tabular}{|c|c|c|c|c|c|c|c|c|}
\hline \multirow{2}{*}{$\begin{array}{c}\text { Constructs } \\
\text { and } \\
\text { Indicator }\end{array}$} & \multicolumn{4}{|c|}{ Comparative Evaluation } & \multicolumn{4}{|c|}{ Noncomparative Evaluation } \\
\hline & $\begin{array}{l}\text { Standar- } \\
\text { dized } \\
\text { Loadings }\end{array}$ & $\begin{array}{c}\text { Cronbach } \\
\text { Alpha }\end{array}$ & $\begin{array}{l}\text { Compo- } \\
\text { site } \\
\text { Reliabi- } \\
\text { lity }\end{array}$ & $\begin{array}{l}\text { Variance } \\
\text { Extracted }\end{array}$ & $\begin{array}{c}\text { Standar- } \\
\text { dized } \\
\text { Loadings }\end{array}$ & $\begin{array}{c}\text { Cronbach } \\
\text { Alpha }\end{array}$ & $\begin{array}{l}\text { Compo- } \\
\text { site } \\
\text { Reliabi- } \\
\text { lity }\end{array}$ & $\begin{array}{l}\text { Variance } \\
\text { Extracted }\end{array}$ \\
\hline \multicolumn{9}{|l|}{ Loyalty: } \\
\hline Sosro & & 0.8956 & 0.8903 & 0.6272 & & 0.8684 & 0.8720 & 0.5850 \\
\hline L1 & 0.576 & & & & 0.527 & & & \\
\hline L2 & 0.682 & & & & 0.687 & & & \\
\hline L3 & 0.729 & & & & 0.742 & & & \\
\hline L4 & 0.941 & & & & 0.892 & & & \\
\hline L5 & 0.961 & & & & 0.911 & & & \\
\hline Fruitea & & 0.8856 & 0.8868 & 0.6154 & & 0.9006 & 0.9008 & 0.6472 \\
\hline L1 & 0.581 & & & & 0.683 & & & \\
\hline L2 & 0.852 & & & & 0.722 & & & \\
\hline L3 & 0.758 & & & & 0.843 & & & \\
\hline L4 & 0.909 & & & & 0.869 & & & \\
\hline L5 & 0.782 & & & & 0.885 & & & \\
\hline Frestea & & 0.9116 & 0.9054 & 0.6616 & & 0.9148 & 0.9084 & 0.7036 \\
\hline L1 & 0.637 & & & & 0.630 & & & \\
\hline L2 & 0.721 & & & & 0.770 & & & \\
\hline L3 & 0.794 & & & & 0.763 & & & \\
\hline L4 & 0.935 & & & & 0.948 & & & \\
\hline L5 & 0.938 & & & & 0.937 & & & \\
\hline
\end{tabular}

The relationship between satisfaction and loyalty is also significant and positive across brands. The standardized path coefficients for comparative evaluation are much stronger than those for noncomparative evaluation, especially for Fruitea and Frestea, ranging 0.642-0.708 compared to 0.607-0.608. Curiously, the standardized path coefficients of Sosro for noncomparative evaluation $(0.714)$ are much stronger than those for comparative evaluation (0.690). Aggregately, the standardized path coefficients for comparative evaluation vary from 0.642 (Fruitea) to 0.708 (Frestea) compared to 0.607 (Fruitea) to 0.714 (Sosro) when the brands are framed in noncomparative evaluations. If the comparison is analyzed more cau-

334 
Darsono \& Junaidi-An Examination of Perceived Quality,Satisfaction, and Loyalty Relationship

Table 3. Key Parameters of Research Model

\begin{tabular}{|c|c|c|c|c|c|c|}
\hline \multirow[b]{2}{*}{ Parameter } & \multicolumn{2}{|c|}{ Sosro } & \multicolumn{2}{|c|}{ Fruitea } & \multicolumn{2}{|c|}{ Frestea } \\
\hline & $\begin{array}{l}\text { Compa- } \\
\text { rative }\end{array}$ & $\begin{array}{l}\text { Non- } \\
\text { Compa- } \\
\text { rative }\end{array}$ & $\begin{array}{l}\text { Compa- } \\
\text { rative }\end{array}$ & $\begin{array}{l}\text { Non- } \\
\text { Compa- } \\
\text { rative }\end{array}$ & $\begin{array}{l}\text { Compa- } \\
\text { rative }\end{array}$ & $\begin{array}{l}\text { Non- } \\
\text { Compa- } \\
\text { rative }\end{array}$ \\
\hline \multicolumn{7}{|l|}{$\begin{array}{l}\text { Standardized } \\
\text { path: }\end{array}$} \\
\hline $\mathrm{Q} \rightarrow \mathrm{S}$ (t value) & $\begin{array}{c}0.790 \\
(12.743)\end{array}$ & $\begin{array}{l}0.642 \\
(9.250)\end{array}$ & $\begin{array}{c}0.734 \\
(11.115)\end{array}$ & $\begin{array}{c}0.570 \\
(7.821)\end{array}$ & $\begin{array}{c}0.507 \\
(6.523)\end{array}$ & $\begin{array}{c}0.329 \\
(4.062)\end{array}$ \\
\hline $\mathrm{S} \rightarrow \mathrm{L}$ (t value) & $\begin{array}{c}0.690 \\
(10.068)\end{array}$ & $\begin{array}{c}0.714 \\
(10.926)\end{array}$ & $\begin{array}{c}0.642 \\
(8.987)\end{array}$ & $\begin{array}{c}0.607 \\
(8.518)\end{array}$ & $\begin{array}{c}0.708 \\
(10.435)\end{array}$ & $\begin{array}{c}0.608 \\
(8.522)\end{array}$ \\
\hline \multicolumn{7}{|l|}{ Goodness of fit: } \\
\hline$\chi^{2}$ & 0.332 & 0.911 & 0.024 & 2.234 & 0.959 & 0.002 \\
\hline $\mathrm{df}$ & 1 & 1 & 1 & 1 & 1 & 1 \\
\hline$P$ value & 0.564 & 0.340 & 0.876 & 0.135 & 0.327 & 0.96 \\
\hline GFI & 0.999 & 0.996 & 1 & 0.991 & 0.996 & 1 \\
\hline AGFI & 0.992 & 0.979 & 1 & 0.949 & 0.977 & 1 \\
\hline CFI & 1 & 1 & 1 & 0.989 & 1 & 1 \\
\hline RMSEA & 0 & 0 & 0 & 0.085 & 0 & 0 \\
\hline
\end{tabular}

tiously, the lower limit value difference $(0.035)$ is greater than the upper limit value difference (0.006). The findings lead to a conclusion that comparative evaluation has relatively higher predictive power than does noncomparative evaluation. Hence, the hypothesis that the strength of relationship amongst perceived quality and satisfaction and loyalty is greater when perceived quality and satisfaction are defined as and measured by comparative evaluation rather than noncomparative or individual evaluation of brand is satisfactorily substantiated.

\section{Discussion}

\section{Perceived Quality-Satisfaction- Loyalty Relationship}

As seen in Table 3, a highly positive relationship exists between perceived quality and satisfaction. Therefore, the findings of this research support the arguments that people form their attitudes towards the performance of products and brands by learning about the different characteristics of the objects and integrating these values into more global affective evalua- 
Gadjah Mada International Journal of Business, September - December 2006, Vol. 8, No. 3

tion. This affective evaluation (satisfaction) is used as a predisposition to compare alternatives and guide final choice and loyalty. This mechanism is also called "belief comparison model" since the objects, three brands of teh botol, are highly comparable (Dabholkar 1994). Implicitly, the findings and theoretical arguments conclude that satisfaction is the mediator of perceived quality-loyalty relationship.

The correlation values between perceived quality and loyalty across brands are lower than those between satisfaction and loyalty (see Table 1). It indicates the role of satisfaction as the mediator of perceived quality-loyalty relationship. (Dabholkar et al. 2000 as cited by Olsen 2002). The proposed research model, with satisfaction as the mediator between perceived quality and loyalty, provides an acceptable fit across brands and for both comparative and noncomparative evaluation. Hence, the result supports Dabholkar's statement that satisfaction acts as a mediator between perceived quality and loyalty.

Dabholkar (1994) reports that people are inclined to make comparison when they have more alternatives. Laroche et al. (1994) also find that people always make comparison when they form their attitudes toward brands. As a result, Dabholkar's (1994); Laroche et al. (1994) studies are supported, regarding that the perceived quality-satisfaction-loyalty relationship gets stronger when perceived qual- ity and satisfaction are measured by comparative evaluation. Thus, perceived quality and satisfaction are better defined as and measured by relative attitudinal framework.

Olsen (2002) finds that satisfaction-loyalty relationship is weaker than perceived quality-satisfaction relationship. However, this research finds contrary results. There are two possible explanations for these contradictory results. First, satisfaction/dissatisfaction is strongly related with specific characteristics of customers. Different characters lead to different satisfaction threshold. Unsatisfactory personal outcomes may be due to factors intertwined with the customer's specific characteristics, and the customer may still rate the brand high or low on quality(Mittal and Lassar 1998; Mittal and Kamakura 2001). Second, on average, variance extracted of perceived quality is lower than that of satisfaction. Low variance extracted of perceived quality indicates that the measurement items cannot fully explain the perceived quality. When a construct with low variance extracted is related to another construct with high variance extracted, the relationship between them tends to be weaker. Therefore, the relationship between perceived quality (low variance extracted) and satisfaction (high variance extracted) is weaker than the relationship between satisfaction and loyalty, regarding that satisfaction and loyalty have high variances extracted. 
Darsono \& Junaidi-An Examination of Perceived Quality,Satisfaction, and Loyalty Relationship

The other differences from previous study (Olsen 2002) are respect to the composite reliability and the variance extracted. Olsen (2002) finds that composite reliability and variance extracted are systematically higher for all constructs and across brands when the constructs are framed in noncomparative evaluation. Olsen (2002) argues that it can be accounted by the fact that noncomparative evaluation may produce a more dimensional similarity halo compared to comparative evaluation. This research basically finds the same result; however, the result does not hold across brands. As seen in Table 2, the composite reliability and the variance extracted of Sosro are systematically higher for comparative evaluation compared to those for noncomparative evaluation. The authors do not have any appropriate reason for this contrary result. However, it is suspected that Sosro's position as a pioneer brand for teh botol must be taken into account. Kardes and Kalyanaram (1992) as cited by Alpert and Kamis (1995) show that customers learn more about a pioneer than about follower brands. This is because the pioneer, as the first entrant in the product category, has features perceived by the customers to be novel and attention-drawing. Hence, there will be more extreme (but generally positive) and confidently held attitudes towards and belief in the pioneer than in the follower brands. Parallel with Alpert and Kamis (1995), Muafi(2001) also finds that pioneer brands are more likely to be retrieved by customers.
Limitations and Implications for Future Research

Even though this research finds that comparative evaluation has relatively higher predictive power than does noncomparative evaluation, one important problem must be noted. The predictive ability in this research is evaluated and compared without taking into account how the brands are framed in the evaluative process, starting from belief (cognitive evaluation) in brand attributes, then integrating them into global affective evaluation. Therefore, future research must emphasize the evaluative process.

Whilst answering the questionnaires, the respondents responded in the basis of whatever materials coming to mind at that time. This is consistent with recent attitude theory suggesting that people do not respond to survey questions on the basis of a single, fixed set of psychological consideration. Lynch et al. (1991) as cited by Laroche et al. (1994) argue that the evaluation is relative, and highly affected by the context surrounding the people. Therefore, the responses tend to count on whatever materials coming to mind at the moment of answering. Furthermore, the particular materials that come to mind depend on the nature of the questions and the manner by which they are posed. As a consequence, perceived quality and/or satisfaction may fail to fully account for the relationship amongst these constructs and their ability to predict or explain loyalty. It appears that the two con- 
Gadjah Mada International Journal of Business, September - December 2006, Vol. 8, No. 3

trary results with Olsen's (2002) study may be owing to the measurement problem of perceived quality. Hence, measurement issues are a central problem in research on perceived quality and satisfaction. Future research must pay a closer attention to: (1) salient attributes for evaluating perceived quality, (2) the sequence of questions on account of question-order effect (Malhotra 2002), (3) measurement scaling provided that many alternatives such as ranking, paired comparison, constant sum scales, etc. can be utilized for comparative evaluation. It gives a potential to replicate this research with different comparative scaling.

With respect to the respondents of this research, the authors suggest the reader to interpret and generalize the results cautiously. Future research should examine and compare perceived quality-satisfaction-loyaltymodel with different samples and settings.

\section{Conclusion and Managerial Implications}

Comparative evaluation has better predictive ability than does non- comparative evaluation. This finding supports the idea that people form their attitudes towards the performance of brands by learning about different characteristics of the objects and integrating them into global affective evaluation. This affective evaluation (satisfaction) is used as a predisposition to compare alternatives and guide final choice and loyalty. Consequently, to create loyal customers, movement along the means-end chain of performance quality, satisfaction, and loyalty is of importance, and the intervention point for marketers is the performance quality of their offerings.

Two managerial implications can be derived from this research. First, quality performance and satisfaction should be measured by comparative or relative attitude towards products and services functionally substitutable subsequent to better predictive power of comparative evaluation. Second, marketers must take into account the performance quality of their offerings to be an important consideration since quality is an important starting point of creating loyal customers.

\section{References}

Alpert, F. H., and M. A. Kamis. 1995. An empirical investigation of consumer memory, attitude, and perceptions toward pioneer and follower brands. Journal of Marketing 59 (October): 34-45.

Assael, H. 1998. Consumer Behavior and Marketing Action ( $6^{\text {th }}$ ed.). Cincinnati, OH: South-Western College Publishing.

Bloemer, J., and K. Ruyter. 1998. On the relationship between store image, store satisfaction and store loyalty. European Journal of Marketing 32: 499-513. 
Bowen, J. T., and S.L. Chen. 2001. The relationship between customer loyalty and customer satisfaction. International Journal of Contemporary Hospitality Management (May): 213-217.

Dabholkar, P. 1994. Incorporating choice into an attitudinal framework: Analyzing models of mental comparison processes. Journal of Consumer Research 21 (June): 100-118.

Dick, A. S., \& K. Basu. 1994. Customer loyalty: Toward an integrated conceptual framework. Journal of the Academy of Marketing Science 22 (2): 99-113.

Dharmmesta, B. S. 1999. Loyalitas pelanggan: Sebuah kajian konseptual sebagai panduan bagi peneliti. Jurnal Ekonomi dan Bisnis Indonesia 14 (3): 73-88.

Fishbein, M., and J. Ajzen. 1975. Belief, Attitude, Intention and Behavior: An Introduction to Theory and Research. Reading, MA: Addison-Wesley.

Hair, J. F., R. E. Anderson, R. L. Tatham, and W. C. Black. 1998. Multivariate Data Analysis ( $5^{\text {th }}$ ed.). Upper Saddle River, NJ: Prentice-Hall International, Inc.

Hallowell, R. 1996. The Relationships of customer satisfaction, customer loyalty, and profitability: an empirical study. International Journal of Service Industry Management 7 (4): 27-42.

Jones, T. O., and W. E. Sasser. 1995. Why satisfied customers defect. Harvard Business Review (November-December): 88-99.

Kandampully, J., and D. Suhartanto. 2000. Customer loyalty in the hotel industry: The role of customer satisfaction and image. International Journal of Contemporary Hospitality Management (December): 346-351.

Kenny, D.A. 1998. Multiple Factor Models. URL: http:/nw3.nai.net/ dakenny/ multiplefactormodel.htm.

2002. Measuring Model Fit. URL: http:/nw3.nai.net/ dakenny/ measuringmodelfit.htm.

Kotler, P. 2000. Marketing Management (Millenium ed.). Upper Saddle River. NJ: Prentice-Hall, Inc.

Laroche, M., M. Hui, and L. Zhou. 1994. A test of the effects of competition on consumer brand selection processes. Journal of Business Research 31: 171-181.

Lau, G. T., \& S. H. Lee. 1999. Consumers' trust in a brand and the link to brand loyalty. Journal of Market Focused Management 4: 341-370.

Malhotra, N. 2000. Basic Marketing Research. Englewood Clifs, NJ: Prentice-Hall, Inc.

Mittal, B., and W. M. Lassar. 1998. Why do customers switch? The dynamics of satisfaction versus loyalty. The Journal of Services Marketing 12 (3): 177-194.

Mittal, V., and W. A. Kamakura. 2001. Satisfaction, repurchase intent, and repurchase behavior: investigating the moderating effect of customer characteristics. Journal of Marketing Research 38: 131-142.

Muafi. 2001. Studi empirik pengaruh pioneer brand pada proses pemilihan brand. Usahawan 30 (8): 3-7. 
Gadjah Mada International Journal of Business, September-December 2006, Vol. 8, No. 3

O'Malley, L. 1998. Can loyalty schemes really build loyalty? Marketing Intelligence and Planning (January): 47-55.

Oliver, R. L. 1999. Whence consumer loyalty. Journal of Marketing 63: 33-44.

Olsen, S. O. 2002. Comparative evaluation and the relationship between quality, satisfaction, and repurchase loyalty. Journal of the Academy of Marketing Science 30 (3): 240-249.

Parasuraman, A., V.A. Zeithaml, and L. L. Berry. 1994. Reassessment of expectations as a comparison standard in measuring service quality: Implications for further research. Journal of Marketing 58: 111-124.

Pritchard, M. P., M. E. Havitz, and D. R. Howard. 1999. Analyzing the commitmentloyalty link in service contexts. Journal of the Academy of Marketing Science 27 (3): 333-348.

Rowley, J., and J. Dawes. 2000. Disloyalty: a closer look at non-loyals. Journal of Consumer Marketing 17 (6): 538-549.

Rowley, J., and J. Dawes. 1999. Customer loyalty - a relevant concept for libraries? Library Management 20 (6): 345-351.

Ruyter, K., and J. Bloemer. 1999. Customer loyalty in extended service settings. International Journal of Service Industry Management 10 (3): 320-336.

Soderlund, M. 1998. Customer satisfaction and its consequences on customer behavior revisited. International journal of service industries Management 9 (2): 169-188.

Strauss, B., and P. Neuhaus. 1997. The qualitative satisfaction model. International Journal of Services Industries Management 8 (3): 236-249.

Syzmanski, D. M., and D. H. Henard. 2001. Customer satisfaction: A meta analysis of the empirical evidence. Journal of the Academy of Marketing Science 29 (1): 16-35.

Teas, K. R., and J. K. Wong. 1992. Item context and stability of entity-based and attributebased multiattribute scaling methods. Journal of Consumer Research 18: 536-545.

Zeithaml, V. A. 1988. Consumer perceptions of price, quality, and value: A means-end model and synthesis of evidence. In B. M. Enis, K. K. Cox, and M. P. Mokwa: Marketing Classics: A Selection of Influential Articles ( $8^{\text {th }}$ ed.). NJ: Prentice Hall, pp. 471-499.

Zeithaml, V.A. 2000. Service quality, profitability, and the economic worth of customers: What we know and what we need to learn. Journal of the Academy of Marketing Science 28 (1): 67-85. 


\section{APPENDICES}

\section{Non-Comparative Evaluation Format}

\section{Satisfaction}

Would you please express your evaluation and feeling on drinking "Sosro" by placing a cross $(\mathrm{X})$ on a scale that best reflects your personal feeling

$\begin{array}{lllllllll}\text { Dissatisfied } & 1 & 2 & 3 & 4 & 5 & 6 & 7 & \text { Satisfied }\end{array}$

$\begin{array}{lllllllll}\text { Unpleasant } & 1 & 2 & 3 & 4 & 5 & 6 & 7 & \text { Pleasant }\end{array}$

Etc. for the other brands....

\section{Perceived Quality}

The following questions are related to your evaluation on specific attributes of teh botol "Sosro" For each attribute, please indicate your personal evaluation by placing a cross $(\mathrm{X})$ on a scale that best reflects your personal feeling

$\begin{array}{llllllllll}\text { Bad scent } & 1 & 2 & 3 & 4 & 5 & 6 & 7 & \text { Nice scent }\end{array}$

$\begin{array}{lllllllll}\text { Bitter taste } & 1 & 2 & 3 & 4 & 5 & 6 & 7 & \text { Sweet taste }\end{array}$

$\begin{array}{llllllll}\text { Dirty packaging } 1 & 2 & 3 & 4 & 5 & 6 & 7 & \text { Clean packaging }\end{array}$

Likewise for the other brands....

\section{Comparative Evaluation Format}

\section{Satisfaction}

How dissatisfied or satisfied you are with the different brands of teh botol by placing a cross $(\mathrm{X})$ on a scale that best reflects your personal feeling

$\begin{array}{llllllllll}\text { Sosro } & \text { Dissatisfied } & 1 & 2 & 3 & 4 & 5 & 6 & 7 & \text { Satisfied } \\ \text { Fruit Tea } & \text { Dissatisfied } & 1 & 2 & 3 & 4 & 5 & 6 & 7 & \text { Satisfied } \\ \text { Frestea } & \text { Dissatisfied } & 1 & 2 & 3 & 4 & 5 & 6 & 7 & \text { Satisfied }\end{array}$

How unpleasant or pleasant you are with the different brands of teh botol by placing a cross $(\mathrm{X})$ on a scale that best reflects your personal feeling

$\begin{array}{llllllllll}\text { Sosro } & \text { Unpleasant } & 1 & 2 & 3 & 4 & 5 & 6 & 7 & \text { Pleasant } \\ \text { Fruit Tea } & \text { Unpleasant } & 1 & 2 & 3 & 4 & 5 & 6 & 7 & \text { Pleasant } \\ \text { Frestea } & \text { Unpleasant } & 1 & 2 & 3 & 4 & 5 & 6 & 7 & \text { Pleasant }\end{array}$


Gadjah Mada International Journal of Business, September-December 2006, Vol. 8, No. 3

\section{Perceived Quality}

For each attribute, please indicate your personal evaluation by placing a cross (X) on a scale that best reflects your personal evaluation

$\begin{array}{llllllllll}\text { Sosro } & \text { Bad scent } & 1 & 2 & 3 & 4 & 5 & 6 & 7 & \text { Nice scent } \\ \text { Fruit Tea } & \text { Bad scent } & 1 & 2 & 3 & 4 & 5 & 6 & 7 & \text { Nice scent } \\ \text { Frestea } & \text { Bad scent } & 1 & 2 & 3 & 4 & 5 & 6 & 7 & \text { Nice scent }\end{array}$

Likewise for the other attributes....

\section{Loyalty}

1. If teh botol "___ " is not available in the store when I need it, I will buy "___ " somewhere else.

2. I intend to keep buying teh botol "

3. If I want teh botol, I only buy "“

4. I have bought teh botol "_ " more often than other brands during the last 3 months.

5. I have bought teh botol "__ " in a larger number than other brands during the last 3 months. 